\title{
Evaluation of Measurement Uncertainty of Some Biochemical Parameters According to ISO/TS 20914 Guidance
}

\section{Bazı Biyokimyasal Parametrelerin Ölçüm Belirsizliğinin ISO/TS 20914 kılavuzuna Göre Değerlendirilmesi}

\author{
Turan Akdag ${ }^{1}$, Saadet Kader ${ }^{2}$
}

${ }^{1}$ Necmettin Erbakan University, Meram ${ }^{2}$ Karapınar State Hospital, Biochemistry

Address correspondence to: Turan Akdag, Necmettin Erbakan University, Meram Vocational School, Konya, Turkey e-mail: turanakdag570@gmail.com

Geliş Tarihi/Received: 4 October 2021 Kabul Tarihi/Accepted: 29 November 2021 Vocational School, Konya, Turkey Laboratory, Konya, Turkey

\begin{abstract}
$\ddot{O z}$
Amaç: Laboratuvar testleri, klinik açıdan tanısal karar vermenin önemli bir parçasıdır. Bu nedenle ölçüm belirsizliği laboratuvar sonuçlarının doğruluğu bağlamında ön plana çıkmaktadır. Bu çalışmada, 29 rutin biyokimya analitinin ölçüm belirsizliği araştırılarak farklı kalite hedefleri ve sonuçları değerlendirildi.

Gereçler ve Yöntem: Çalışmada Mindray BS-800 otoanalizörü ile Ekim 2020 - Nisan 2021 tarihleri arasında çalışılan 29 analitin ölçüm belirsizliği analiz edilmiş ve ISO/TS 20914 Kılavuzuna göre değerlendirilmiştir. Ölçülen değerlerin tanımlanması, ölçümü etkileyen faktörlerin belirlenmesi, metot ölçüm belirsizliği, kalibrasyon belirsizliği, kalite kontrol verilerinden oluşan dış belirsizlik ve ölçüm belirsizlikleri belirlenmiştir. Ayrıca kalite kontrol verilerinden oluşan eksternal belirsizlik ve ölçüm belirsizlikleri de ölçülmüştür. Bulgular: Ölçülen analitlerden trigliserit, demir, fosfor, GGT, kreatin kinaz, ürik asit, lipaz ve CRP' nin her iki seviyede EFLM ve Ricos toplam izin verilen hata (TEa \%) değerlerine göre limit içerisinde olduğu görülürken, ALT' nin 2. seviyede ve 1. seviyede Ricos' a göre geçtiği, amilazın 2. seviyede geçtiği, AST' nin 2. seviyede Ricos'a göre geçtiği, total kolesterolün 2. seviyede geçtiği, HDL' nin 2. seviyede geçtiği, potasyumun 2. seviyede Ricos'a göre geçtiği, total bilirubinin 2. seviyede Ricos'a göre geçtiği, LDH' nin 2. seviyede EFLM' ye göre geçtiği, BUN' un ise 2. seviyede geçtiği belirlenmiştir.

Sonuç: Ölçüm sonuçlarının dağılımını gösteren bir değer olarak ölçüm belirsizliği, laboratuvar testlerinin ölçüm ve test sonuçlarının değerlendirilmesinde önemli rol oynar. Çalışmamızda EFLM ve Ricos' un toplam izin verilen hatasına (\%TEa) göre trigliserit, demir, fosfor, GGT, kreatin kinaz, ürik asit, lipaz ve CRP analitlerinin her iki düzeyde de uyumlu olduğu, diğer parametrelerin ise uyumlu olmadığı görülmektedir. Daha ileri ve kapsamlı çalışmalara intiyaç vardır
\end{abstract}

Anahtar Kelimeler: Ölçüm belirsizliği, analiz, kalite kontrol, eksternal belirsizlik

Abstract

Aim: Laboratory tests are an important part of clinical diagnostic decision. Therefore, measurement uncertainty stands out in the context of the accuracy of the laboratory results. In the study, different quality objectives and results were evaluated by investigating the measurement uncertainty of 29 routine biochemistry analytes.

Material and Methods: The measurement uncertainty calculation model of 29 analytes were analyzed with the Mindray BS-800 autoanalyzer between October 2020 and April 2021, and evaluated according to ISO/TS 20914 Guideline. The external uncertainty and measurement uncertainties consist of definition of the measured values, determination of the factors affecting the measurement, method measurement uncertainty, calibration uncertainty, and quality control data were determined.

Results: The measured analytes as triglyceride, iron, phosphorus, GGT, creatine kinase, uric acid, lipase and CRP were compatible with EFLM and Ricos total allowable error (TEa\%) values at both levels. ALT was compatible with level 2 and level 1 according to Ricos, amylase, AST, total cholesterol, HDL and total bilirubin were compatible with level 2 according to Ricos. In addition, LDH and BUN were compatible with level 2 according to EFLM.

Conclusion: Measurement uncertainty shows the distribution of measurement results which displays an important role in the evaluation of measurement of laboratory tests. In our study, it was determined that triglyceride, iron, phosphorus, GGT, creatine kinase, uric acid, lipase and CRP analytes were compatible with both levels according to the total allowable error (TEa\%) of EFLM and Ricos. Also, it was observed that the other parameters were not compatible with both levels. Further and comprehensive studies are needed.

Key words: Measurement uncertainty, analysis, quality control, external uncertainty

Cite this article as: Akdag T, Kader S. Evaluation of Measurement Uncertainty of Some Biochemical Parameters According to ISO/TS 20914 Guidance. Selcuk Med J 2021;37(4): 328-333

Disclosure: None of the authors has a financial interest in any of the products, devices, or drugs mentioned in this article. The research was not sponsored by an outside organization. All authors have agreed to allow full access to the primary data and to allow the journal to review the data if requested. 


\section{INTRODUCTION}

Biochemical quantitative analyses are based on the results of many clinical decisions. The measurement uncertainty is a quantitative indicator of the quality of the measured results. From another respect, it may show the expanding to which the result represents the exact value. If the measurement uncertainty presented with the results, correct information about the quality of the measurements will be arrive to the users (1). Measurement uncertainty may provide information on the level of confidence on the measurements. Although the concept of precision expresses uncertainty, more comprehensive uncertainty calculations should be made by evaluating more component effects in biochemical measurements (2). The information which presented with the International Vocabulary of Metrology (VIM2), Guide to the expression of uncertainty in measurement (GUM1), ISO/IEC and VIM3 documents are provide metrological techniques for the calculations. However, there is no consensus on how the calculation should be made, yet (3).

There are many imprecise reasons that may cause measurement uncertainty in laboratories such as sampling method, sample matrix, environment conditions, uncertainty of instruments, errors in calibration, methods and procedures (4). While calculating the measurement uncertainty, the standard uncertainty values from each uncertainty source can also be calculated separately. From the studies, the expanded uncertainty value is calculated by increasing the confidence interval of the uncertainty by multiplying the total uncertainty by the coverage factor (k) (5). In addittion, the total errors are equal to the sum of the systematic and random error in the measurement procedures (6). Total allowable error (TEa) is an analytical quality requirement that adjust the uncertainty (random error) and bias (systematic error) of a single test result or measurement within tolerable limits. Clinical Laboratory Implementation Amendments 1988 (CLIA'88) criteria specify the legally permissible maximum error limits of the substances which being measured in the laboratories. There are different recommendations for the TEa calculation on the basis of biological variability coefficients in European countries. If the total error for an analyte is within the limits of TEa, it's assumed that the diagnostic efficiency of the system seems as appropriate (7). The ISO/TS 20914 guide became available in 2019. This ISO document is presented as a guide for the practical application of measurement uncertainty estimation for the clinical laboratory. The use of the coefficient of variation and the potential for misuse requires certain concerns about clarification between changes in measurement conditions and the potentially misleading, pooled variance and uncertainty of measurement, calculation of the international normalized ratio (INR), rules for evaluating unified uncertainty in functional relationships, and some of the clarified measurement uncertainties are also presented in the guidance $(8,9)$.

In the study, we aimed to evaluate of 29 routine biochemistry analytes according to ISO/TS 20914 measurement uncertainty guidance which studied in Karapınar State Hospital laboratory.

\section{MATERIAL AND METHODS}

The study was carried out with 29 biochemical analytes between October 2020 and April 2021. In the study, analytes were measured with Mindray BS-800 autoanalyzer (glucose, total protein, albumin, BUN, uric acid, creatinine, creatinine kinase, cholesterol, HDL-cholesterol, triglyceride, sodium, potassium, chloride, magnesium, calcium, phosphorus, amylase, lipase, lactate dehydrogenase, total bilirubin, direct bilirubin, AST, ALT, alkaline phosphatase, GGT, CRP, iron and iron binding capacity). The measurement uncertainty of these analytes was calculated and performed according to the ISO/TS $20914 \mathrm{MU}$ guidance. The bias values were calculated from external quality control results according to the ISO 20914 guideline. In the study, desirable bias values were obtained from the Westgard's biodatabase (www.westgard.com/biodatabase1.htm). According to the ISO 20914 guideline, if the bias estimated from EQC testing is within allowable error limits, bias can be ignored. The bias (\%) values were lower than the desirable bias (\%) values in our study (Table 1 ). The reagent, calibrator and control lot number were followed, and there was no change during this period. This retrospective study was approved by the Necmettin Erbakan University Meram Faculty of Medicine, Non-Invasive Clinical Research Ethics Committee (Decision Number: 2021/3228).

\section{Statistical Analysis}

The combined standard uncertainty calculation $\mathrm{U}(\mathrm{y})$ was performed using the $\sqrt{ }(\mathrm{uRw}+\mathrm{ucal})$ (URw: long term precision, Ucal: calibrator uncertainty) formula. Within the scope of ISO/TS 20914 guideline, standard deviation (SD) of internal quality control data was accepted as uRw. Ucal data was obtained from Mindray Company. Internal quality control data (between 01.10.2020 and 01.04.2021) were used for 
the uRw account. Two levels of internal quality control material were used for each analyte. Uncertainty calculations were made separately for both levels. The SD of the internal quality control results was calculated. The expanded measurement uncertainty calculation $U(y)$ was found by multiplying the result $\mathrm{u}(\mathrm{y})$ with the coverage factor $(\mathrm{k})(\mathrm{k}=2)$. The percent of expanded uncertainty of measurement (Urel $\%)$ was calculated using the formula ' $U(y) /$ internal quality control mean*100'. Obtained measurement uncertainty data were compared with the current Tea\% values of EFLM and Ricos.

\section{RESULTS}

The expanded uncertainty, standard combined uncertainty and measurement uncertainty from sources were calculated for 29 different analytes and analyzed with Mindray BS-800 autoanalyzer (Table 1). The TEa\% values of 29 different parameters were calculated in the study and shown in the Table 2. Triglyceride, iron, phosphorus, GGT, creatine kinase, uric acid, lipase and CRP were compatible with EFLM and Ricos total allowable error (TEa\%) values at both levels. ALT was compatible with at level 2 and level 1 according to Ricos, amylase, AST, total cholesterol, HDL and total bilirubin were compatible with level 2 according to Ricos. In addition, LDH and BUN were compatible with level 2 according to EFLM. The other parameters were not compatible with Westgard and Ricos specification limits at both levels.

\section{DISCUSSION}

The measurement uncertainty, characterized by the distribution of values accordance with the measured quantity, is associated with the measurement result. Moreover, each measurement result has a measurement uncertainty which consists of different stages such as analysis, incomplete information and sampling (10). So, the measurement uncertainties together with the measured results can be widely used in the future (11). There is an understanding of the essential role of reference measurement systems in clinical biochemistry, but general agreement has not yet been reached on user-performing secondary tuning via new patient samples to minimize or eliminate the bias. To eliminate bias is important mission for laboratory organizations serving patients and healthcare professionals (12). A study proposed that specifying the measurement uncertainty along with the laboratory results of the patient may affect the interpretation of the test results, as clinically (13). Although the determination of measurement uncertainty is not obligatory, clinical laboratories are required to have measurement uncertainty information related to the tests being studied (14).

Acccording to EFLM and Ricos, TEa\% values

Table 1. Values of different biochemical parameters $(n=29)$

\begin{tabular}{|c|c|c|c|c|c|c|c|c|c|c|c|c|}
\hline Test & $\begin{array}{l}\text { Level I } \\
\text { SD } \\
\text { (uRw1) }\end{array}$ & $\begin{array}{l}\text { Level } 1 \\
\text { Mean }\end{array}$ & $\begin{array}{l}\text { Level } 2 \\
\text { SD } \\
\text { (uRw2) }\end{array}$ & $\begin{array}{l}\text { Level } 2 \\
\text { Mean }\end{array}$ & $\begin{array}{l}\text { CAL } \\
\text { C }\end{array}$ & $\begin{array}{l}\text { CAL U } \\
\text { (Ucal) }\end{array}$ & $\begin{array}{l}\text { Level } 1 \\
\text { combined } \\
\text { standard } \\
\text { uncertainty }\end{array}$ & $\begin{array}{l}\text { Level } 1 \\
\text { expanded } \\
\text { measurement } \\
\text { uncertainty }\end{array}$ & $\begin{array}{l}\text { Level } 2 \\
\text { combined } \\
\text { standard } \\
\text { uncertainty }\end{array}$ & $\begin{array}{l}\text { Level } 2 \\
\text { expanded } \\
\text { measurement } \\
\text { uncertainty }\end{array}$ & $\begin{array}{l}\text { Bias } \\
(\%)\end{array}$ & $\begin{array}{l}\text { Desirable } \\
\text { Bias (\%) }\end{array}$ \\
\hline Albumin $(\mathrm{g} / \mathrm{dL})$ & 0.10 & 31.3 & 0.14 & 48.0 & 33.7 & 1.31 & 1.31 & 2.63 & 1.32 & 2.63 & 1.32 & 1.43 \\
\hline Magnesium (mg/dL) & 0.08 & 2.05 & 0.14 & 3.37 & 1.22 & 0.08 & 0.11 & 0.23 & 0.16 & 0.31 & -0.9 & 3.2 \\
\hline T.Protein $(\mathrm{g} / \mathrm{dL})$ & 0.26 & 46.6 & 0.76 & 78.7 & 50.8 & 1.22 & 1.25 & 2.50 & 1.44 & 2.87 & -2.1 & 1.36 \\
\hline $\operatorname{ALP}(\mathrm{U} / \mathrm{L}) \quad 6.33$ & 97.5 & 11.3 & 225 & 248 & 8.58 & 10.7 & 21.3 & 14.2 & 28.4 & -2.7 & 6.72 & \\
\hline ALT (U/L) 2.57 & 57.6 & 4.96 & 123 & 104 & 4.78 & 5.43 & 10.9 & 6.89 & 13.8 & -2.2 & 11.48 & \\
\hline Amylase (U/L) & 2.84 & 85.7 & 4.10 & 205 & 194 & 7.74 & 8.25 & 16.5 & 8.76 & 17.5 & 0.9 & 26.2 \\
\hline Creatinine $(\mathrm{mg} / \mathrm{dL})$ & 0.09 & 1.03 & 0.19 & 3.73 & 3.99 & 0.15 & 0.17 & 0.35 & 0.24 & 0.48 & -1.5 & 3.96 \\
\hline AST (U/L) 1.54 & 49.5 & 8.39 & 145 & 109 & 5.97 & 6.16 & 12.3 & 10.3 & 20.6 & -3.0 & 6.54 & \\
\hline T.chol (mg/dL) & 2.21 & 84.7 & 4.94 & 188 & 158 & 5.14 & 5.60 & 11.2 & 7.13 & 14.3 & 1.4 & 4.1 \\
\hline Calcium (mg/dL) & 0.29 & 8.59 & 0.83 & 12.8 & 10.9 & 0.23 & 0.37 & 0.74 & 0.86 & 1.71 & 0.6 & 0.82 \\
\hline HDL-chol (mg/dL) & 1.09 & 28.3 & 2.86 & 78.6 & 69.2 & 2.63 & 2.85 & 5.69 & 3.88 & 7.77 & -1.3 & 5.61 \\
\hline Potassium (mEq/L) & 0.18 & 3.55 & 0.17 & 6.66 & 3.48 & 0.02 & 0.18 & 0.36 & 0.17 & 0.35 & -1.6 & 4.8 \\
\hline Triglyceride (mg/dL) & 3.87 & 114 & 5.42 & 200 & 131 & 4.78 & 6.15 & 12.3 & 7.23 & 14.5 & 1.0 & 9.57 \\
\hline T. Bilirubin $(\mathrm{mg} / \mathrm{dL})$ & 0.08 & 1.01 & 0.26 & 3.60 & 5.08 & 0.20 & 0.22 & 0.43 & 0.33 & 0.66 & 1.1 & 8.95 \\
\hline D. Bilirubin (mg/dL) & 0.05 & 0.81 & 0.15 & 2.17 & 2.68 & 0.13 & 0.14 & 0.29 & 0.20 & 0.40 & 5.6 & 14.2 \\
\hline Iron $(\mu \mathrm{g} / \mathrm{dL})$ & 11.5 & 104 & 21.1 & 216 & 37.8 & 0.93 & 11.5 & 23.0 & 21.2 & 42.3 & -4.7 & 8.8 \\
\hline LDH (U/L) 8.04 & 170 & 8.39 & 307 & 266 & 6.76 & 10.5 & 21.0 & 10.8 & 21.5 & -1.5 & 2.2 & \\
\hline Iron-binding $(\mu \mathrm{g} / \mathrm{dL})$ & 12.6 & 155 & 15.7 & 213 & 105 & 2.68 & 12.9 & 25.8 & 16.0 & 31.9 & 0.4 & 6.4 \\
\hline Sodium $(\mathrm{mEq} / \mathrm{L})$ & 2.20 & 113 & 1.49 & 135 & 120 & 0.39 & 2.23 & 4.46 & 1.54 & 3.08 & -2.2 & 3.1 \\
\hline BUN $(\mathrm{mg} / \mathrm{dL})$ & 3.16 & 40.8 & 2.89 & 113 & 100 & 3.83 & 4.97 & 9.93 & 4.80 & 9.59 & 0.2 & 5.57 \\
\hline Phosphorus (mg/dL) & 0.18 & 4.56 & 0.24 & 9.62 & 1.68 & 0.09 & 0.20 & 0.40 & 0.26 & 0.51 & 1.2 & 4.6 \\
\hline GGT $(U / L) \quad 3.06$ & 58.2 & 17.2 & 262 & 114 & 3.93 & 4.98 & 9.96 & 17.6 & 35.2 & -0.5 & 11.06 & \\
\hline Creatine kinase $(U / L)$ & 4.70 & 145 & 10.1 & 266 & 350 & 11.6 & 12.5 & 25.0 & 15.4 & 30.8 & -1.9 & 11.5 \\
\hline Uric acid $(\mathrm{mg} / \mathrm{dL})$ & 0.30 & 5.07 & 0.26 & 9.54 & 5.09 & 0.29 & 0.42 & 0.83 & 0.39 & 0.79 & 2.8 & 4.87 \\
\hline Glucose $(\mathrm{mg} / \mathrm{dL})$ & 3.16 & 102 & 7.14 & 232 & 195 & 9.98 & 10.5 & 20.9 & 12.3 & 24.5 & 1.4 & 1.8 \\
\hline Lipase (U/L) & 2.00 & 44.4 & 2.96 & 103 & 97.4 & 4.40 & 4.83 & 9.66 & 5.30 & 10.6 & 0.1 & 11.31 \\
\hline $\mathrm{CRP}(\mathrm{mg} / \mathrm{dL})$ & 0.69 & 9.63 & 2.52 & 53.2 & 9.10 & 0.75 & 1.02 & 2.04 & 2.63 & 5.26 & 12.2 & 21.8 \\
\hline Chloride (mEq/L) & 3.29 & 87.20 & 2.31 & 108 & 85.10 & 0.48 & 3.33 & 6.66 & 2.36 & 4.71 & -0.9 & 0.5 \\
\hline
\end{tabular}


Table 2. Expanded measurement uncertainty of Ricos and EFLM (TEa\%) values of biochemical parameters $(n=29)$

\begin{tabular}{lllll}
\hline Test & Level $\mathbf{1 ,}$ Urel\% & Level $\mathbf{2 ,}$ Urel\% & Ricos (TEa\%) & EFLM (TEa\%) \\
\hline Albumin & 8.39 & 5.48 & 4.07 & 3.40 \\
Magnesium & 11.08 & 9.29 & 4.80 & 4.00 \\
T.Protein & 5.36 & 3.65 & 3.63 & 3.50 \\
ALP & 21.88 & 12.62 & 12.04 & 10.50 \\
ALT & 18.84 & 11.16 & 27.48 & 16.10 \\
Amylase & 19.24 & 8.55 & 14.60 & 13.20 \\
Creatinine & 33.72 & 12.94 & 8.87 & 7.40 \\
AST & 24.92 & 14.17 & 16.69 & 13.60 \\
T.cholesterol & 13.22 & 7.56 & 9.01 & 8.70 \\
Calcium & 8.65 & 13.41 & 2.55 & 2.30 \\
HDL-cholesterol & 20.09 & 9.88 & 11.63 & 11.10 \\
Potassium & 10.20 & 5.24 & 5.61 & 4.80 \\
Triglyceride & 10.75 & 7.20 & 25.99 & 27.00 \\
T. Bilirubin & 42.69 & 18.23 & 26.94 & - \\
D. Bilirubin & 35.38 & 18.39 & 44.50 & - \\
Iron & 22.17 & 19.63 & 30.70 & - \\
LDH & 12.34 & 7.02 & 11.40 & 7.70 \\
Iron-binding & 16.66 & 14.95 & - & - \\
Sodium & 3.96 & 2.27 & 0.73 & 0.70 \\
BUN & 24.37 & 8.46 & 15.55 & 17.80 \\
Phosphorus & 8.87 & 5.30 & 10.11 & 9.70 \\
GGT & 17.10 & 13.43 & 22.11 & 18.90 \\
Creatine kinase & 17.23 & 11.57 & 30.30 & 22.60 \\
Uric acid & 16.46 & 8.25 & 11.97 & - \\
Glucose & 20.47 & 10.57 & 6.96 & 6.50 \\
Lipase & 21.75 & 10.25 & 37.88 & 14.20 \\
CRP & 21.22 & 9.88 & 56.60 & 50.70 \\
Chloride & 7.63 & 4.37 & 1.50 & 1.30 \\
\hline
\end{tabular}

TEa: Total Allowable Error, Urel \%: expanded uncertainty of measurement

of triglyceride, iron, phosphorus, GGT, creatine kinase, uric acid, lipase and CRP analytes as were observed compatible with both levels. While ALT was compatible with level 2 and level 1 according to Ricos, amylase, AST, total cholesterol, HDL, potassium, total bilirubin were compatible with level 2. LDH and BUN were compatible with level 2 according to EFLM in our study. In a study, Kutukcu el reported that albumin, amylase, alanine transaminase, total bilirubin, direct bilirubin, blood urea nitrogen, calcium, creatinine kinase, chlorine, creatinine, glucose, potassium, lipase, magnesium, sodium, total protein, phosphorus, CRP, aspartate transaminase and troponin-I test results were compatible with CLIA'88 limits, but the $\mathrm{MU}$ results of albumin, calcium, chlorine, magnesium, sodium and total protein were not compatible with Westgard limits (15). In another study, the uncertainty of $\mathrm{HbA}_{2}$ measurement was found to be as $12.4 \%$ in the Tosoh HLC 723 G8 device (16). Dulgeroglu et al. (17) declared that there was \pm 0.4 measurement uncertainty at the $6 \%$ medical decision level for $\mathrm{HbA} 1 \mathrm{c}$, and they proposed that these result may affect the clinical decision.
From the reports, it is assumed that the uncertainty calculations of interlaboratory and intralaboratory performance data may facilitate the calculation of measurement uncertainty (18). Recently, ISO is implementing a new project to evaluate measurement uncertainty in medical laboratories (ISO/NP TS 20914 Medical Laboratories-Practical Guide for the measurement of uncertainty) (19). Ayyıldız et al. (20) were evaluate the measurement uncertainty of dihydroepiandrosterone sulfate analysis (DHEA-S), and they found measurement uncertainty of DHEA-S as $95 \%$, and the confidence interval as $+15.5 \%$. They declared that the calculation of measurement uncertainty in tests may provide transparency in the evaluation of the results.

Ricos et al. (21) defined bias and total error to adjust analytical quality within acceptable limits in terms of desirable properties for uncertainty. In a measurement uncertainty study which conducted by Cubukcu et al. (22) they evaluated 14 parameters and found that the measurement uncertainties of $\mathrm{TSH}$, estradiol, LH, progesterone, prolactin and vitamin B12 were within the allowable limits, U-unilateral 
FT3 and U-unilateral ferritin exceeded the defined TEa\%, and also U-FT3 and U-ferritin (pUEQAS\%) were at low values. Moreover, they concluded that the measurement uncertainties of FT4, cortisol, DHEAS, FSH, testosterone and folate were not within the specification limits. The adequate application of modern medicine is unlikely without the results of tests carried out in clinical laboratories. The measurement of these tests is performed by a series of complex precision instruments and various automated electronic equipment using test procedures. However, no test result is completely certain. These uncertainties and errors in test results may also vary depending on the operator skill, measurement system, environmental situations, and other factors. So, the concept of uncertainty of measurements was needed to precise the uncertainty $(23,24)$.

The principal assumption in calculating measurement uncertainty is related with information for the identification and correction of all systematic errors. The quality of a measurement is associated with the uncertainty about random and systematic error is taken into account on the correct basis (25). The $U$ values calculated from all the tests which analyzed by Mindray BS-800 device was within the Ricos and EFLM total error limits, and we proposed that these values could be used in our laboratory. Also, it is suggested that improvements should be made to reduce error sources for these tests.

\section{CONCLUSION}

In our study, we aimed to compare the TEa \% values of EFLM and Ricos according to the current ISO/TS 20914 guideline by calculating the measurement uncertainty of clinical biochemistry parameters that are frequently studied in our hospital. All conditions in the laboratory may affect the uncertainty. For this reason, uncertainty should be constantly monitored. Errors related medical decisions are becoming more important than before. For this reason, it is important to report the measurement uncertainty to the clinician with the results. To the best of our knowledge, there are very limited studies on this topic. So, comprehensive and multicenter studies are needed.

Peer-review: Externally peer-reviewed.

Authorship Contributions: Concept - T.A, S.K. ; Design - S.K., Supervision - T.A, S.K Funding - None; Materials - S.K. Data collection \&/or processing - S.K. Analysis and/or interpretation - T.A., S.K., Literature search - T.A., S.K: Writing - T.A., S.K. ; Critical review - T.A., S.K.
Conflict of interest: Authors declare that there is no conflict of interest between the authors of the article.

Financial conflict of interest: Authors declare that they did not receive any financial support in this study.

Address correspondence to: Turan Akdağ, Necmettin Erbakan University, Meram Vocational School, Konya, Turkey,

Phone: +905056597350,

e-mail: turanakdag570@gmail.com

\section{REFERENCES}

1. Bakır F, Laleli Y. TS EN ISO/IEC 17025 Kapsamında akreditasyona teknik hazırlık. Turk J Biochem 2006;31(2):96101.

2. Ellison SLR, Rösslein M, Williams A. EURACHEM/CITAC Guide. Quantifying Uncertainty in Analytical Measurement 2000:141-16.

3. Aytekin M, Cevlik T, Emerk K. Describing an ideal model for calculating the uncertainty of measurements in a clinical laboratory. Clin Biochem 2009;42(4-5):321-2.

4. White $\mathrm{GH}$, Farrance I. AACB Uncertainty of measurement working group. Uncertainty of measurement in quantitative medical testing: A laboratory implementation guide. Clin Biochem Rev 2004;25(4):S1-24.

5. Anonymous. EURACHEM/CITAC Guide CG 4. Quantifying Uncertainty in Analytical Measurements, 2000: (QUAM:2000. P1).

6. Westgards QC. Rilibak - German Guidelines for Quality Westgard. Tools, Technologies and Training for Healthcare Laboratories, https://www. westgard.com/rilibak.htm. 2019.

7. Taga Y, Aslan D, Güner G, et al. Tıbbi laboratuvarlarda standardizasyon ve kalite yönetimi. TBD Yay 2000:46-89.

8. Farrance I, Frenkel R, Badrick T. ISO/TS 20914:2019 - a critical commentary. Clin Chem Lab Med 2020;58(8):118290.

9. ISO/TS 20914. Medical laboratories - Practical guidance for the estimation of uncertainty. Geneva, Switzerland: International Organization for Standardization 2019:67-73.

10. Anonymous. P903: Policy on estimating measurement uncertainty for ISO 15189 testing laboratories. American Association for Laboratory Accreditation 2014:22-8.

11. Ellison SLR, Williams A. EURACHEM/CITAC guide quantifying uncertainty in analytical measurement. Eurachem 2012: 4-6.

12. Kallner A, Khorovskaya L, Pettersson T. A method to estimate the uncertainty of measurements in a conglomerate of instruments/laboratories. Scand J Clin Lab Invest 2005;65(7):551-8.

13. White $\mathrm{GH}$, Farrance I. AACB Uncertainty of measurement working group. Uncertainty of measurement in quantitative medical testing: A laboratory implementation guide. Clin Biochem Rev 2004;25(4):S1-24.

14. Han San EA. Technical guide 4: A Guide on measurement uncertainty in medical testing. The SAC Accreditation Programme by SPRING Singapore 2013:1-51.

15. Kütükçü $A$, Özçelik $F$, Yekrek $M M$, et al. The importance of single or combined use of measurement uncertainty and the reference change value in the diagnostic evaluation of 
biochemical tests. Hamidiye Med J 2020;1(1):7-16.

16. Ellidağ HY, Eren E, Aydın Ö, et al. Talasemi taramasında HbA2'nin ölçüm belirsizliği. Turk Clin Biochem J 2014;12(1):31-5.

17. Dülgeroğlu Y. İyon değiştirici kromatografi yöntemi ile ölçülen HbA2 ve HbA1c' nin ölçüm belirsizliğinin tespiti. Turk Hij Den Biyol Derg 2017;74(4):299-306.

18. Çelebiler A, Serin $H$, Güleç $D$, et al. Klinik biyokimya laboratuvarında ölçüm belirsizliği: Pratik uygulama. Turk J Biochem 2011;36:362-6.

19. Milinkovic N, Ignjatovic S, Sumarac Z, et al. Uncertainty of measurement in laboratory medicine. J Med Biochem 2018;37:1-10.

20. Ayyıldız SN. Uncertainty of measurement evaluation of dehydroepiandrosterone sulfate analysis. Turk Clin Biochem J 2016;14(2):131-7.
21. Westgard J. Basic QC practices. Training in statistical quality control for medical laboratories. Westgard QC 2010:175-89.

22. Çubukçu HC, Yavuz Ö, Devrim E. Uncertainty of measurement for 14 immunoassay analytes: Application to laboratory result interpretation. Scand J Clin Lab Invest 2019;79(1-2):117-22.

23. Bell S. A beginner's guide to uncertainty of measurement measurement good practice guide. NPL United Kingdom 1999;2:11.

24. Plebani M. Errors in clinical laboratories or errors in laboratory medicine. Clin Chem Lab Med 2006;44(6):750-9.

25. Krouwer JS. Setting performance goals and evaluating total analytical error for diagnostic assays. Clin Chem 2002;48(6):919-27. 